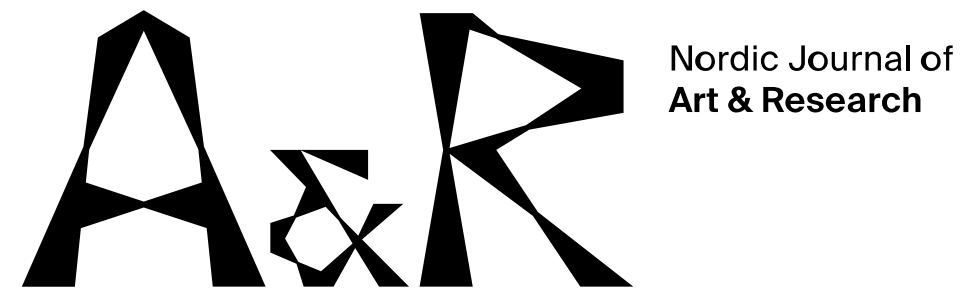

\title{
Exercises in intra-acting: A zone of potential
}

\section{And an exercise about not dropping out. 'Tape yourself to a green chair.'}

\author{
Kristina Junttila ${ }^{1}$ \\ UoT - The Arctic University of Norway
}

\begin{abstract}
This article is about the participatory performance event Speak for yourself (Snakk for deg sjøl) performed mainly for teenagers at schools through the Norwegian Cultural Schoolbag program (Den kulturelle skolesekken), but also for an open audience at Hålogaland Theatre and the Arctic Arts Festival. The center of the discussion concerns what has agency to initiate various ways of participation and produce a zone of potential in this performance event. The author is one of the artists of the performance and thus the diffractive analysis is informed by her role as artistresearcher. The study's theoretical framework is inspired by the theory of agential realism from physician and feminist theorist Karen Barad.
\end{abstract}

The analysis suggests that the initiation of participation is a complex process influenced by both human and non-human performative agents in intra-action with each other. This study will especially focus on the formulation of exercises, performance objects, social media, multiplicity and affect $t$ as performative agents in this performance event. The study indicates that being attentive to the performative

1UoT - The Arctic University of Norway, Academy of Music. kristina.junttila@uit.no 
Kristina Junttila. Exercises in intra-acting: A zone of potential

agents at play and the kind of participation they produce can potentially create a space where there is room for inclusion, diversity, and unpredictability. This kind of zone of potential also has value for other participatory projects in the intersection between pedagogy and art.

Keywords: audience participation, exercise, zone of potential, performative gent, performance event, art pedagogy, unpredictability, diffraction, artist-researcher

\section{Introduction}

The gazes from the empty chairs dig into my spine the moment I enter the room. The bookshelves with many hundreds of pages stand there, covered in dust. The desks lock the chairs beneath them. The chalkboard smiles a white smile, reminding me of yesterday's lesson. The light from the sun is shining through the curtains and creating hallways of light. I open the window to let in some fresh air. I am looking forward to meeting the others. The air from the window hits me. Great. I am ready for a new day at school.

This description of entering a classroom was written by a young Norwegian pupil, and it was the opening text in the participatory performance Speak for yourself (Snakk for deg sjø/). In this article, using Speak for yourself as material, my aim is to discuss what initiates and produces participation in performing arts, and how this can create a zone of potential. The analysis is inspired by Karen Barad's theory of 'agential realism' (Barad, 2007), and I explore how working on participation is a complex and unstable matter. This study is situated in debates about participatory and socially engaged arts, as well as at the intersection between pedagogy and the arts, and a new materialist understanding of practice. Using this perspective, I discuss what needs to be considered by artists, teachers and others who wish to facilitate inclusive situations that allow for a zone of potential. By 'zone of potential' I am suggesting a framed temporary space or site where there is room for a plurality of potentials and ways of being. I regard the zone of potential as an event where something new can take place - both the planned and the unforeseen. According to Professor in Performance Studies Richard Schechner (2006), an event is a result of 'restored behaviour'. What makes an event unique is its particular recombination of the restored behaviour, which is always rebuilt in a new way (Schechner, 2006). The future is constantly being reshaped through actions and encounters, and it is becoming through events (Deleuze, 1992). It is through the recombination of our 
Kristina Junttila. Exercises in intra-acting: A zone of potential

actions and encounters that we are created once again and that something new can occur.

In this study, the zone is produced by the performance, and the focus is on what kind of temporary potentials the performance can produce. A potential means 'that which is possible'; it is an unrealised ability. Yet, the zone of potential is not judged on a certain right or normative potential. Philosopher Giorgio Agamben (1999) emphasises that all potentialities also include the potential of not being active and that being passive can also give room for ideas that have not yet found their form. In the performance, we deliberately wanted to accept all kinds of participation; both active and passive. The zone of potential is created by the framing of the performance, and how the actions and encounters intra-act with each other. The zone of potential includes multiple ways of being in the space, it is a temporary, diverse and inclusive zone that can potentially produce new beginnings.

Today, many artists and researchers are exploring the notion of participation in the arts and performance (Bala, 2018; Berg, 2017; Bishop, 2012; Jackson, 2011; Kester, 2004). My point of departure is that all live performances are participatory, with participants producing their own experience in relation to their personal backgrounds: 'Every spectator is already an actor in her story; every actor, every man of action, is the spectator of the same story' (Rancière, 2009, p. 17). However, different disciplines have distinct notions of participation, depending on their aesthetic and political history, and conventions of the artform (Bala, 2018). In this multifarious discussion, a need has been identified for awareness about what kind of competence is required to work on participation. The present study is in line with the notion that both artistic and pedagogical competence are needed, as addressed by Lisa Nagel and Lise Hovik (2014). These researchers have carried out studies of participation in children's performances in particular, and they have discussed what is required to produce deep participation, where the participants are dedicated to the experience. One competence that Nagel (2013) raises is the need for knowledge about children's reality and experience. My study contributes to this field by focusing on teenagers as audience participants and on how to develop new forms of participatory practices specifically for this age group as audience participants.

My study is informed by the theoretical framework of agential realism and new materialism, where the focus is on how the agency is not only about how we, as humans, act upon each other, but also how the material-discursive practice has a constitutive power (Barad, 2003). I frame audience participation as a complex and time-consuming practice with the focus on how the material-discursive practice also 
Kristina Junttila. Exercises in intra-acting: A zone of potential

produces participation. In the educational field, there have been an increasing number of studies of how we are interdependent with our environment; the classroom, the way we organise time and the objects that surround us are all examples of such factors (Hickey-Moody \& Page, 2016; Lenz Taguchi, 2011, 2012). In many ways, this interdependence and how the whole environment influences the learning experience is transferable to the performance situation. In the artistic research project Baby Body, Tone Pernille Østern and Lise Hovik (2017) used a similar theoretical framework, looking at how co-creation functions as a methodological agent in a creative research project. They discussed how co-working on the material and co-creation are performative agents and drive the creative process. The current study also centres the analysis on performative agents, but my focus is on how they create participation.

In this article, I explore how participation produces and is produced as a complex and unstable matter. By using a 'diffractive' research methodology, the centre of the analysis concerns how performative agents, in intra-action with each other and the environment, initiate various ways of approaching audience participation in the performance Speak for yourself. Further, the study discusses what the potential of the participation could be, creating a zone of potential.

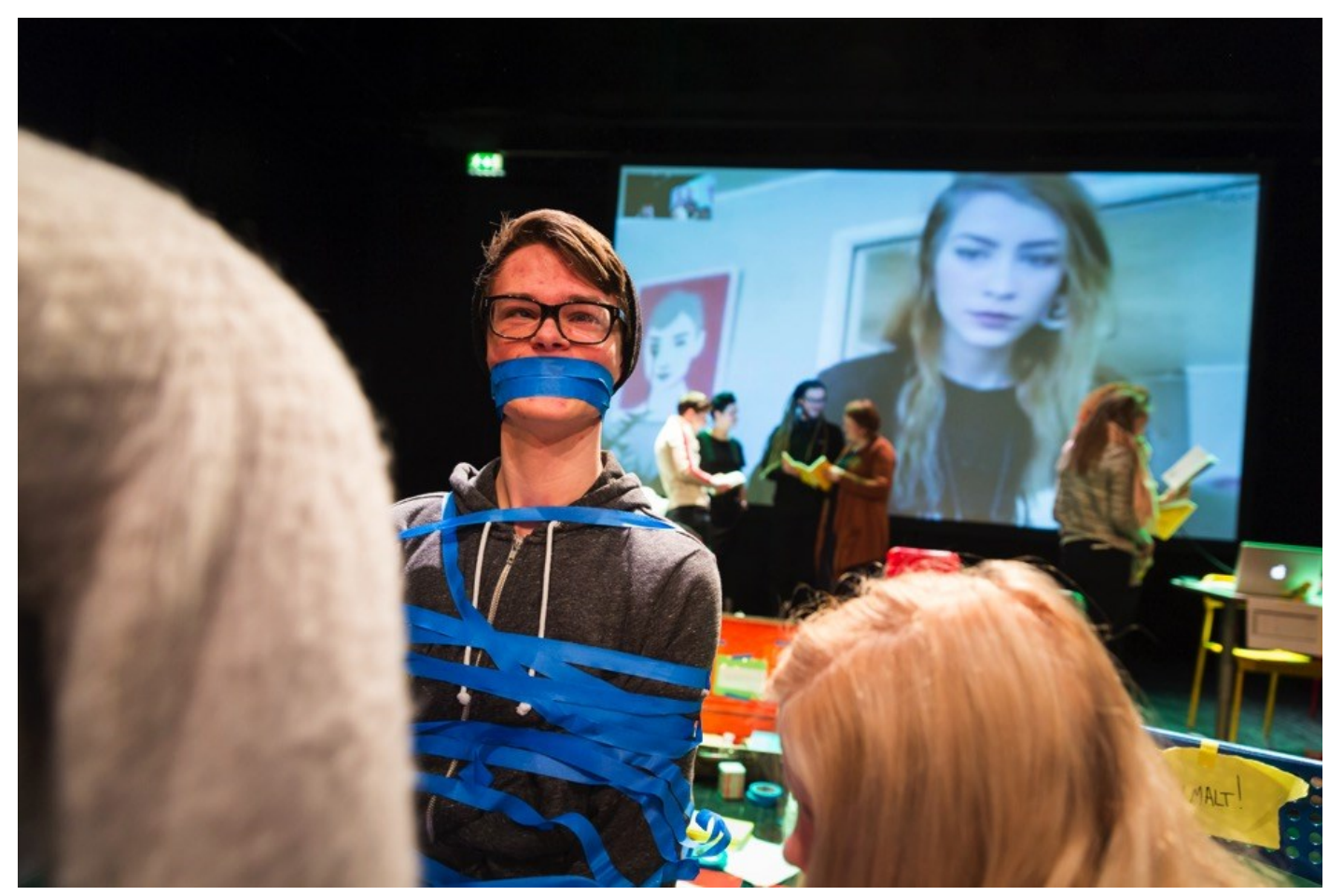

Image 1. The audience doing the exercise about not dropping out: 'Tape yourself to a green chair'. The audience was informed that photos would be taken and have given permission for publication here. Photo: Marius Fiskum. 


\section{Speak for yourself}

Speak for yourself premiered in March 2015 at Hålogaland Theatre, the regional professional theatre of Northern Norway. It was performed at the Arctic Arts Festival in Northern Norway, as well as at schools in the counties of Troms and Finnmark in 2016 and 2017 through the Cultural Schoolbag. ${ }^{2} \mathrm{~A}$ trailer of the performance is available online. ${ }^{3}$ It was co-created and performed by artists, including the author of this article, and teenagers. Three teenagers performed live during the performance, while one teenager performed via Skype. The roles and ways of influencing the project were fluid, and the performing teenagers played an essential part in making the project what it was. As I was part of the artistic team, this study was conducted from within the performance, and my embodied practice is part of the apparatus I am researching. (Barad, 2007; A.-L. Østern \& Moxness, 2017; T. P. Østern \& Hovik, 2017; Sayal-Bennett, 2018).

Speak for yourself was carried out within the framework of a larger, multifaceted programme in the field of pedagogy and art, which sought to promote the voices of young people by facilitating writing workshops and creating performances and related activities. Texts and themes from the workshops provided important material that was used in the performance. The workshops took seriously the complexities, ongoing processes and existential questions the teenagers encountered in their everyday lives (Stien, Kramvig, \& Liabø, 2015). The theme of the performance focused on being an adolescent and being in school, but, primarily, it was about quitting school. In Northern Norway, up to $40 \%$ of upper secondary students left before taking their final exams during the period $2010-2014^{4}$, the years preceding the performance. The topic has attracted a lot of attention in public discourse and is regarded as a significant political challenge. However, the voices of the pupils are seldom at the forefront of the discourse. In the performance, we wanted to include and involve multiple voices, including the voices of the performing teenagers and audience participants. This article focuses on the participation of the audience, and not the performing teenagers. Most of the performances were shown for school classes, and teenage pupils formed the majority of the audience participants. However, the

\footnotetext{
${ }^{2}$ The Cultural Schoolbag (Den Kulturelle Skolesekken) is a Norwegian national programme designed to ensure that all school pupils in Norway experience professional art and culture of all kinds.

${ }^{3}$ https://vimeo.com/173454481

${ }^{4}$ https://www.ssb.no
} 
Kristina Junttila. Exercises in intra-acting: A zone of potential

audiences did not just consist of teenagers, and there will be examples of different age groups as audience participants in this article as well.

\section{Theoretical framework}

Agential realism, developed by physician and feminist theorist Karen Barad (2003, 2007 ), is seen as part of feminist relational materialism and, taking a wider perspective, 'posthumanism'. There are different directions within posthumanism, but a common point of view is that non-humans also have agency, allowing them to create the future and what is becoming in the world. To take examples from the performance that is the subject of this study, the worn-out chairs on the stage, talking virtual humans and backpacks the audience participants brought with them were agents serving to create the performance experience. Further, in cases where the research turns its focus towards humans, aspects like affect, the body and energy can also be identified as agents and co-creators of the performance (Sandvik, 2015). Looking at technology as an agent and viewing how our co-existence with contemporary technology and how technology shapes our everyday lives are important parts of posthumanism. This is addressed, for example, by feminist scholar and historian of science and technology Donna Haraway (Donna J. Haraway, 1991) in the groundbreaking essay 'Cyborg Manifesto'.

The focus on how all the components have agency and affect each other relates to the importance of the whole complex landscape of creating change (Hickey-Moody \& Page, 2016). The knowledge lies in the intertwining of - and relationships between many components, all of which affect each other and, thus, can potentially disturb dominant practices and create new constellations. In studying what initiates participation in the complex landscape of the performance event, I study what has agency or, in general terms, what has the 'ability to cause some kind of change' (Tillman, 2015, p. 32).

Barad (2007) uses the term performative agents for active agents with the capacity to change a situation in intra-action with each other. According to Barad, intra-action is an alternative to interaction; entities are not separated from each other before the interaction takes place. Rather, in intra-action, the entities do not perform separately from each other, and the boundaries between them are indistinct and fluid (Barad, 2003, 2007; Lenz Taguchi, 2012). All the matter and active performative agents emerge from each entanglement with the audience participants and reconfigure the performance, making participation a complex and time-consuming practice. 
Kristina Junttila. Exercises in intra-acting: A zone of potential

Barad's (2003) understanding of performativity is useful for understanding how material is an active agent in performance. Language has had too much power, while matter appears to be the only thing that has not been given importance. Materiality has a constitutive power as well, and it is an active agent in creating the world. Materiality is not important in itself but in the meaning it gains as it interfaces with other phenomena-in intra-action. This way of thinking, that everything matters and has agency, is in many ways implemented in how artists think and work when we create new performances. The performance objects, the energy level and how we use technology create the performance experience. This notion is one reason why the theoretical framework of posthumanism is increasingly used as an inspiration by artists and artistic researchers.

In agential realism, the focus is not on understanding what something is, but, rather, on how it comes into being. The world is being created or coming into being in intraaction. Further, in agential realism, how the world comes to be and how it comes to be known are not separate but entangled processes (Barad, 2007). In this entanglement, we cannot fully plan the future. The performative agents shape each other and take responsibility for the event and what it will become: 'Intra-actions are constraining but not determining. That is, intra-activity is neither a matter of strict determinism nor unconstrained freedom. The future is radically open at every turn' (Barad, 2003, p. 826).

Although Barad states that the future is radically open, this does not mean that we should neglect taking responsibility for it. Rather, we can conclude that any performative engagement in the world entails intimate responsibility. There is no content or intention without an ethics or responsibility, and Barad calls this ethicoonto-epistemology (Boyd, 2015, p. 11). All the performative agents that are at play in the Speak for yourself performance have an ethical dimension and responsibility tied to them, and this needs to be continuously considered. As a result, one aim of this study is to develop methods where we are conscious of how we are creating the future through the whole complex performance landscape.

\section{A diffractive research methodology}

A 'diffractive' analysis highlights different possibilities and potentials that depend on how the phenomena considered intra-act with other agents; this contrasts with being reflective, which involves looking back and reflecting the same image as the original (T. P. Østern \& Hovik, 2017). All materials 'have a performative dimension, and are 
Kristina Junttila. Exercises in intra-acting: A zone of potential

involved in the production of the world rather than offering a neutral and objective description of it' (Sayal-Bennett, 2018, paragraph 10).

In this study, I have been both the artist and researcher, and I have conducted the analysis from within, through my embodied practice. I am engaging in a diffractive analysis where the researcher is engaged in intra-action with the material and is intertwined with what is being investigated. Diffractive analysis was first proposed by Haraway (1997) and Barad (2007). It looks at the research data through an embodied engagement. The focus is on the material effects of difference and how to study the relationship and co-creation between humans and non-humans. The practice of diffraction is at the centre of the study, and Barad (2007) defines it as 'accounting for how practices matter' (Barad, 2007, p. 88). There are no clear borders between the theoretical framework and practice. Diffractive analysis has similarities to other practice-based and performative research methodologies where theory and practice inform each other and expand and give new insight into each other.

I use varied empirical material based on lived experience, as well as a journal I wrote after nine public performances, recorded interviews with two of the co-creators and the manuscript, video and images of the performance event. I choose to read these data not as stable knowledge, but as elements in intra-action with each other and me. Data in this regard are: 'different human and non-human forces creating, generating, and reproducing knowing, affect, and sensory experiences' (KoroLjungberg, Löytönen, \& Tesar, 2017, p. 2). Using a diffractive analysis, I identify the potential of the material and its differences, as well as the effect it produces. I am oriented towards what the agents do, how they create possibilities, rather than meaning (Scott, 2015). This gives me an opportunity to become attuned to how differences are being created and what effect they have on initiating participation.

In the following, I present the diffractive analysis, in which performative agents have a special role in initiating participation while intra-acting with other agents. I try to bring to light the moments when the intra-action between agents changes something and takes new forms; this can be called the diffractive cut. The distinct agencies do not precede, but rather emerge through their entanglements and intra-action with other agents. The agent is not a fixed essence but is produced and productive, generated and generative (Barad, 2007). Diffraction happens when different performative agents intra-act. In performing the analysis, I look for moments when the agents, such as the performers, performance objects, theatre context and social media, intraact and something unexpected emerges. I analyse what performative agents create participation in intra-action and how they do so differently. The performative agents I 
discuss are the formulation of exercises, performance objects, social media, multiplicity and affect.

\section{The performance event speaks for itself: analysis of how participation is produced}

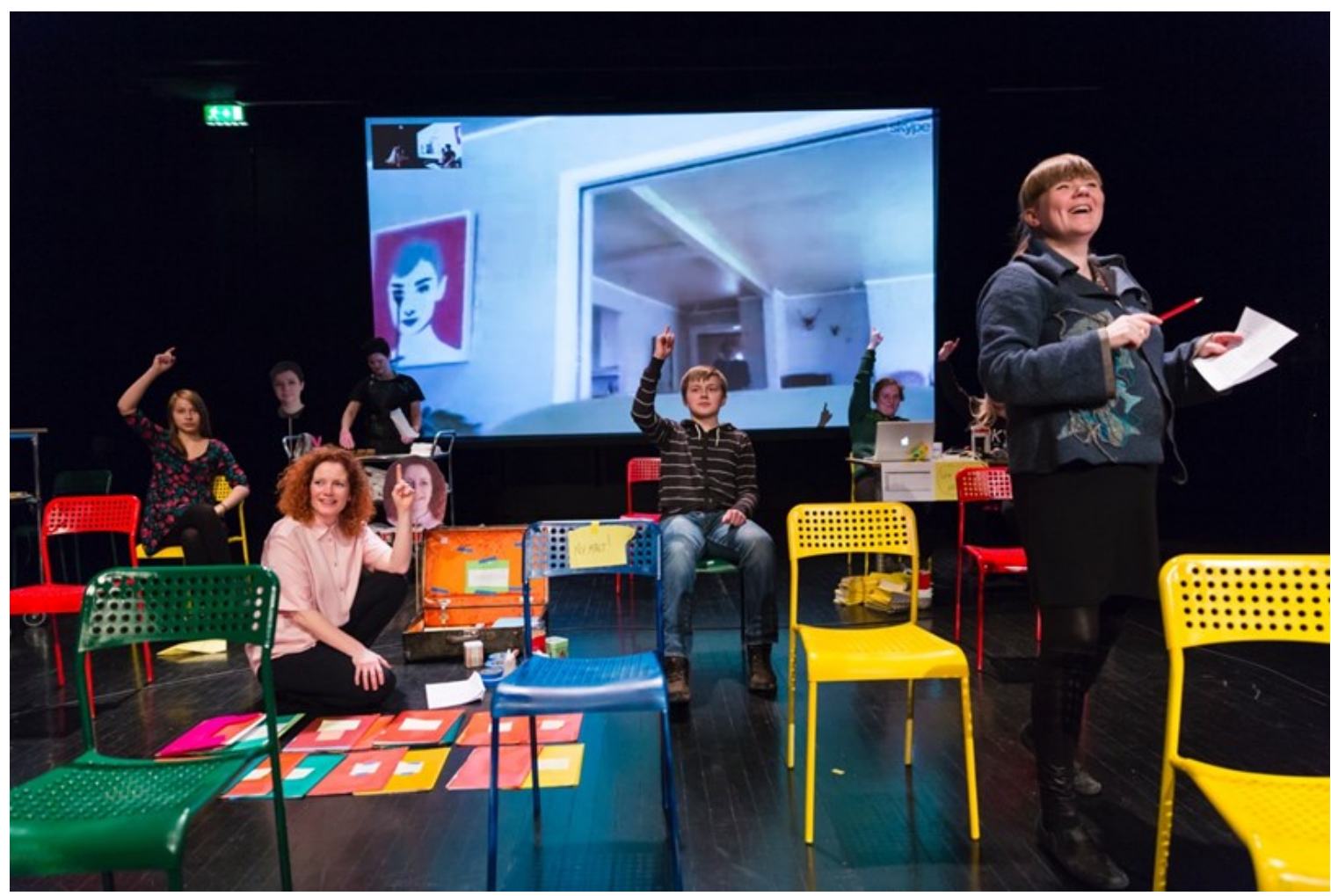

Image 2: The audience participants are given different forms of exercises through oral and written instructions at several junctures. The exercises manifest themselves in different ways during the performance event. Here, the performers ask those in the room to raise their hand if they sometimes fall asleep at work or in school. Performers $i$ the image have given permission for it to be published here. Photo: Marius Fiskum

\section{The formulation of exercises as a performative agent}

In Speak for yourself, the audience participants are given different forms of exercises through oral and written instructions at several junctures. These instructions are carefully planned and scripted, and they explore a form frequently used in schools, where exercises are traditionally used to activate pupils. The exercises manifest themselves in different ways during the performance event; members of the audience 
Kristina Junttila. Exercises in intra-acting: A zone of potential

are asked to raise their hand and some are offered adapted education; 5 at the end of the performance event, everyone is given a book of written exercises, which they can complete independently as they choose. These exercises are literal, asking the audience participants to do specific exercises. They inherently initiate participation and are very straightforward to do, making it easy for the audience to react to them. They can thus potentially lead to an event. They work as enabling constraints, a restriction that makes something possible (Manning, 2014).

At the beginning of each performance, four audience participants could choose to participate by carrying out adapted tasks: one audience member could assist the lighting technician, one could hang out with the scenographer and assist in making food, one could walk around and document the performance with a video camera and one could help the sound designer, who had a place on the stage, to disrupt the performance. Disruptions included different kinds of sound triggers, giving notes to the audience, blowing up balloons, flying paper airplanes or other activities devised on the spur of the moment. The reason why we wanted to include these adapted tasks was to disrupt the hegemonic order, as well as to reference actions and methods that are common in the classroom setting. However, the disruptions were often rather tame, perhaps because they were too staged, and the sound designer had to push the audience to dare to be disruptive. In contrast, the audience participant assigned this task during our first performance on the school tour took up so much space that the other text and actions, which the rest of the audience usually had no problem noticing, were lost in his disruptions. The pupil involved said that he had never personally been disruptive in the classroom, but that, when he was asked to disturb, it triggered something in him:

Earlier, I said that our task was to disrupt, and we should be as disruptive as possible. But after the experience where this turned out to be a problem, I changed how I formulated the exercise to say that I and the audience beside me could be disruptive by filling in empty holes - to stick something in between. I said that we should think about the in-between spaces that are already there, and beyond that, we should be on top of everything. This requires us to listen to what is really happening. Because

\footnotetext{
${ }^{5}$ Schools in Norway are obliged to offer adapted education (tilpasset opplæring) to pupils who have a special need for it (https://www.udir.no/laring-og-trivsel/tilpasset-opplaring/hva-er-tilpasset-opplaring/).
} 
Kristina Junttila. Exercises in intra-acting: A zone of potential

if you are going to fill in empty spaces, you must listen. My experience is that those who had this task after we made the change were much more attentive to what was happening around them. (Rakel, sound designer. Recorded dialogue, 20.10.2016)

This diffractive cut shows the importance of the formulation of the exercise and what happens in the intra-action with the audience participant. In this example, the context of the school and the earlier experiences of that particular audience charged the atmosphere of the performance. Even though we wanted to accept all kinds of participation, we noticed that these disturbances altered the performance in a direction that did not serve the theme. This resulted in a slight reformulation of the exercise in later performances, making it more challenging for the participant to perform, while, at the same time, making more sense in the bigger picture. The exercises are formulated so that they are accessible and understandable, but this incident shows that we need to reformulate and readjust each exercise to fit the situation. Small adjustments of the formulation can take the participation and performance in completely new directions. Since everything is in motion, the 'attention to fine details is a crucial element of this methodology' (Barad, 2007, pp. 90 - 92). A constant reconfiguring of the exercises, impulses or enabling constraints through different intra-actions is important when initiating participation. 


\section{Performance objects as a performative agent}

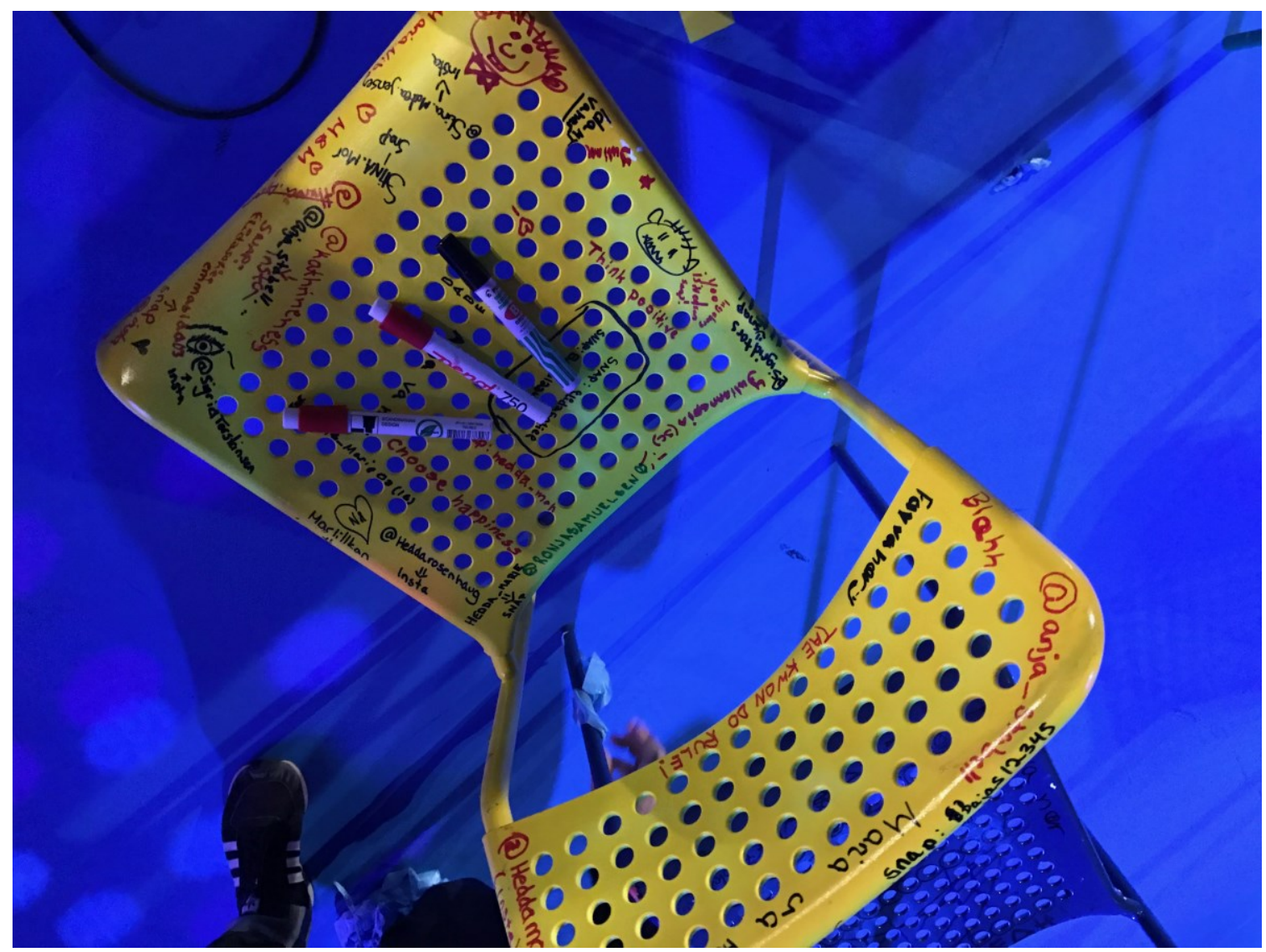

Image 3. Chair on stage for the audience to write on at the end of the performance. Photo: Kristina Junttila.

I approached two audience members in their forties. They were well dressed. I had two markers in my hand and asked if they wanted to write on the chairs. First, they were embarrassed; they laughed and asked if they looked like typical taggers. 'No, I just thought it could be fun-but you could do something else. Perhaps read a text?' 'No, we want to write graffiti'. The marker calls your name; the marker invites you to write. The worn-out chairs are asking to be written on. The tape is for those who want to play. (Journal, 14.10.2016)

This is an example of my thoughts, written after one of the performances that was open to the public, where most of the audience were adults. The concrete object, the marker that they can hold in their hands, makes it safe to participate through the object and its materiality. The marker and worn-out chairs do not pre-exist with agency, but instead emerge through the intra-action with the adult audience participants. In this way, they become performative agents. This diffractive cut gives 
Kristina Junttila. Exercises in intra-acting: A zone of potential

them the possibility of carrying out an act that is forbidden in other contexts. Intraaction with the marker thereby recreates possibilities for who the audience participants can become and what they can do. In this new context, the objects allow much wider usage than they do when in normal use in school, and the audience participants can explore the objects differently. This wider usage triggers imagination, freedom and action, and it gives the performance objects agency to initiate participation in a direction we had not planned.

Another example of an object engaged in a diffractive cut comes from one of the first performances for teenagers at Hålogaland Theatre. At the end of the performance, the audience participants could choose between 14 exercises. One of the exercises read, 'An exercise in not dropping out. Tape yourself to a green chair'. Blue tape was available for the audience to use. Suddenly, in the centre of a full stage, we noticed that four or five audience members were enthusiastically taping one of their friends increasingly tightly in a manner that could be hazardous, and we had to intervene. This example of what can happen when the audience has an open invitation to intraact with performance objects has similarities with the well-known performance Rhythm 0 carried out by Marina Abramovic in 1974. She placed 72 objects on a table, and the audience members were invited to use the objects as they desired, while Abramovic was standing passively beside the table. Some audience members became increasingly aggressive with the objects, cutting her clothes; they even 'nicked bits of flesh from her neck. Later, someone put a loaded gun in her hand and pushed its nozzle against her head' (Goldberg, 2000, p. 246). The result was that the performance had to be stopped, and, as Peggy Phelan (2004) points out, it became an important work in 'the ongoing post-war conversation about the ethics of the act: what does it mean to act when full knowledge of the consequence of your act cannot be known in advance?' (p. 19).

The situation in which the audience group intra-acts with the tape raises questions about the freedom - and responsibility - of the audience, as well as the choice of performance objects, which become active agents. Barad (2007) emphasises the 'ethical obligation to intra-act responsibly in the world's becoming' (p. 178). An immediate response could be that the exercise and the tape were problematic, because they invited acts that should not have been allowed to happen. However, one of our aims was to allow for risk-taking situations and work deliberately with the risk audience participation gives rise to. When instigating participation, it is not possible to pre-plan all the entanglements. Our way of taking ethical considerations into account in this situation was to be aware of how the situation developed, and to 
Kristina Junttila. Exercises in intra-acting: A zone of potential

take the necessary action if we saw that it was needed. We did not ban this exercise from future performances. Instead, we adjusted the number of available tape rolls and kept a close eye on how this exercise developed each time.

\section{Social media as a performative agent}

As mentioned above, the notion that technology has agency in our lives is important. There are no clear boundaries between the human and the technological. Which governs which is not given, and we can no longer choose whether we want to relate to technology; instead, we should look at what technology can do to us (Donna J. Haraway, 1991). The bodily intra-action with social media, the live engagement between body and machine, is producing and being productive. In our engagement with social media, we are performing our identity. However, we have little control of how this is conceived, how it is spread and commented on or how the framing of the specific social media, such as Facebook, Skype or Snap Chat, affects how we perform our identity (Marabelli \& Page, 2018). Social media play an important role in the performance, as well as in the everyday life of the audience participants.

In Speak for yourself, there was a small screen on which the audience participants could read a Facebook chat taking place in real time between teenagers sitting in the audience, and the audience was given a few minutes' break during the performance to check their phones for new personal messages. In my journal, after a performance, I wrote about how I could sense that the audience was relieved when they had this opportunity: 'I saw it in their faces: Yes! I can see whether I have any new messages.' (14.10.2016)

This diffractive cut surprised the audience, mostly in a positive way. It allowed them to withdraw into their own familiar space where we, the performers, would not interfere for a few minutes. One effect of this diffractive cut produced by the agency of the audience participants' phones was that the members of the audience were given the opportunity to bring their personal lives into the performance room, which made it easier for them to participate by being themselves, as they were. This was strengthened by using other social media, especially through a large screen onstage where Wilde, a young girl, took part in the performance via Skype. Wilde had quit school twice, and during the performance, we would talk to her about her experiences; she was present for the whole performance via Skype, sharing her personal life story, and this meeting and ongoing communication with the 'real world' encouraged the audience members to share. At the end of each performance, it was 
Kristina Junttila. Exercises in intra-acting: A zone of potential

possible for a few audience members to have a personal chat with Wilde, and this became a popular slot.

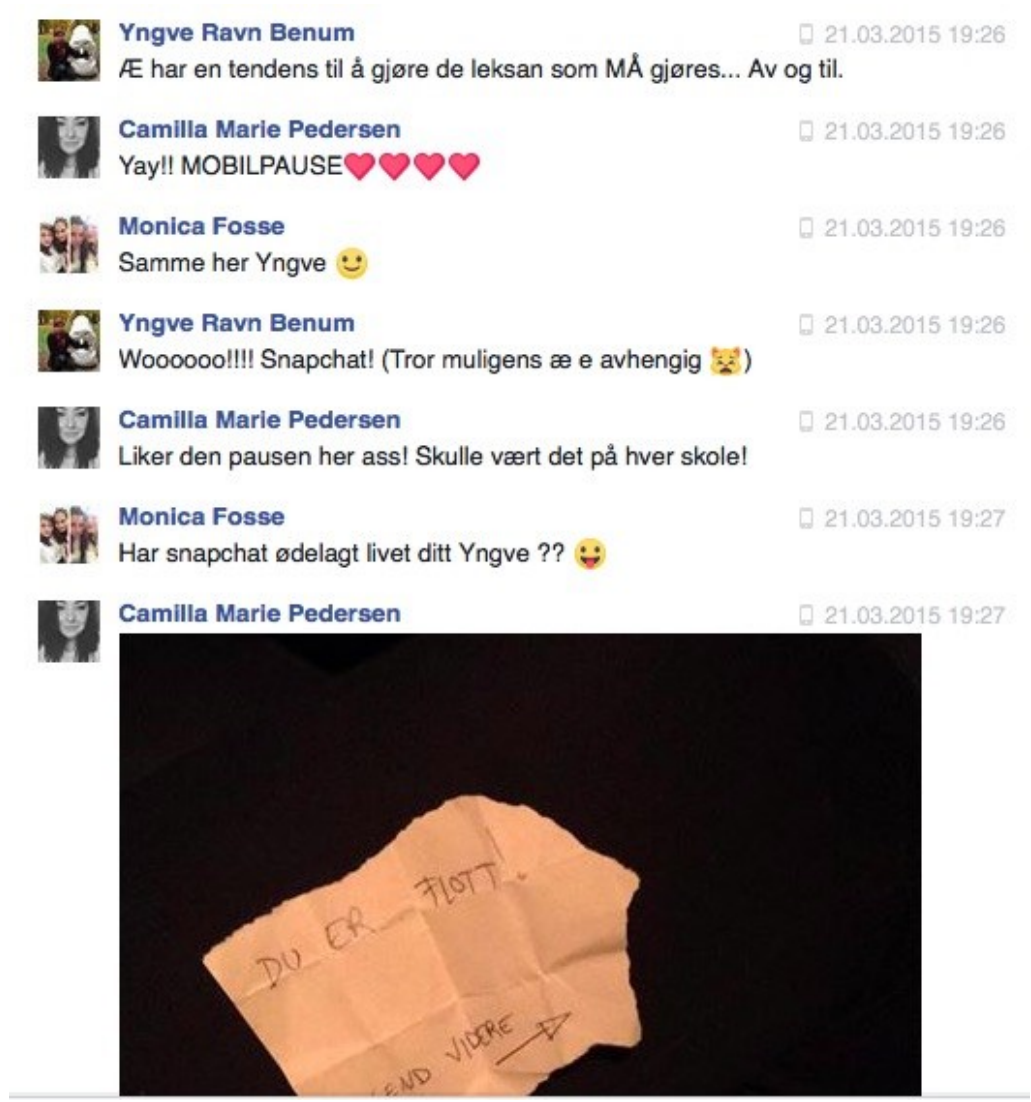

Figure 4: Screenshot of Facebook chat visible to the audience. The chat is part of the performance and is written by young performers seated among the audience, commenting on what is happening in the performance space. The performers writing in the chat have given permission for it to be published here.

Introducing everyday life into the performance space through Wilde and her personal stories can be compared to the works of the theatre collective Rimini Protokoll, among others. Rimini Protokoll stage what they call the experts of everyday life, where people who have hands-on experience of the theme of the performance are performing and form the defining aspect of the documentary work. This is often done through a technical device, such as directing audience participants via phone from a call centre in Calcutta (Balme, 2019). Here, via the medium of Skype, the audience was invited to intra-act virtually with Wilde. The medium intensifies the experience of intimacy and immediacy. Each audience member could intra-act with her personally, so her story and presence became a key access point of the performance. 


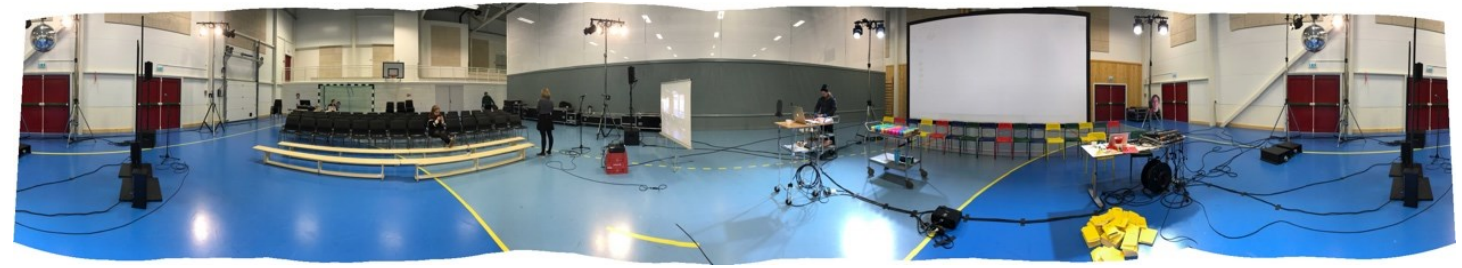

Figure 5: Picture of the setup of the performance when performed in a school gym. Photo: Kristina Junttila.

\section{Multiplicity as a performative agent}

There were a couple things I came to think about when reflecting on why initiating participation works. I think a key component is that there is so much difference and diversity. We are among the audience. We are close to them; we have tried to say hello to them by walking in between them and talking to them one on one. And then I think it matters that there are so many points of focus onstage. If it is the kind of performance with only one focus all the time, it is a higher threshold to break into it. There are disruptions: We have a screen here and another screen there, we have the constant projections of teenagers on the side stage, many of whom read and talk... It never feels like we break one focus. And then I think it matters that we are who we are. That we have personalities they can feel safe with, and we are different. (Rakel, recorded dialogue, 20.10.2016)

In the comment above, Rakel, the sound designer, reflects on the importance of multiplicity and diversity as agents initiating participation. She points out that the performance has many focuses and uses multimodal ways of communication simultaneously. In intra-action with how secure we are with our differences as the performers, this initiates different kinds of responses and ways of participating. The selection of different expressions, different texts and a heterogeneous group of teenagers on stage is important and creates a feeling of recognition for many in the audience. This helps to create a space where the audience participants feel that they also have room to act - there is space to be who they are. This includes those who do not wish to actively participate in the exercises. They can be together with the rest of the audience just by being in the same room. 
Kristina Junttila. Exercises in intra-acting: A zone of potential

While the audience participants are free to choose how they want to participate at the end of the performance, there is also a multiplicity of options, with fourteen exercises to choose from. In the first performances, we only mentioned a few of the exercises and asked the audience to read about the other possibilities in a book. However, we noticed that they only did the exercises we had mentioned, so we adjusted the performance to describe all of them. We realised that it made a difference when we mentioned all the different variations and did not expect the audience to read about them independently. This diffractive cut showed that where we put the focus affects what the performance produces. Given our conscious choice to use multiplicity to enhance inclusion and initiate a variety of possible ways of participating, we needed to constantly ensure that we were actually displaying the multiplicity. Giving space for entanglements and multiple focus makes it more likely that the performance will initiate a variety of participations, and this can open a zone of experimentation and potential.

One teacher came and told me that he loves the kind of chaos that was happening, when all the students are just doing something. He said that he just came from that kind of chaos - from a science experiment. He called it 'organised chaos'. It is such a great feeling when a teacher sees what we are doing. (Journal, 18.10.2016)

\section{Affect as a performative agent}

Affect is the last performative agent I highlight and it has a greater focus on the human aspect and the role of the participants than the previous ones did. Since this study is about initiating participation, we cannot exclude the agency of the audience participants and their reactions, although it can be more problematic to analyse when we talk about the human aspect as Other. To affect and be affected is to be in an encounter, and it concerns an immediate participation in the events of the world (Massumi, 2015). Affect is a non-conscious experience of intensity; it is the body's way of preparing for action through an intense experience. Our senses are affected and prepare for action. We cannot draw a clear boundary between the individual and her/his surroundings. Sometimes, the real message or language is of less importance than the affectual resonance of the message source. The music, atmosphere and different media can have a biological effect on the body and transfer affect. When we are affected, this can initiate something (Shouse, 2005). Creating affect via intense experiences is perhaps one of the most important tasks of art. However, it is also one of the most difficult because, as artists, we cannot control how the audience participants react, and knowing that someone is affected does not say anything about 
Kristina Junttila. Exercises in intra-acting: A zone of potential

the content of their affect. In this performance, we wanted to include all kinds of affectual responses that emerged from the intra-action with the performance. By witnessing and acknowledging affect, we encouraged immediate participation:

I am standing here alone. One teenager alone. I stand here nervous and alone. One teenager. I feel lonely up here, no one to talk to about how I feel. I am a teenager. I am one of thousands of teenagers who stand, sit or lie down. I am a teenager. You are a teenager. We are many thousands of teenagers. Why do we feel so lonely? (Text from the performance, written by a teenager)

One of the last things that happens during the performance is that a teenager standing in the audience reads the above text. The audience participants are onstage, and they look up at the teenager, who is using a microphone; the light fades out and a big disco ball spins on the ceiling. When the reading is finished, a melancholy song fades in while the disco ball continues to spin. This is an intense moment in the performance, and it is an affective moment for many people; the audience is touched. When the performance toured different schools, this text was read by a teenager I picked from the audience, and it intensified the affective experience that many people knew the person reading the text.

The decision to ask one of the audience participants to read this emotional text alone in front of the audience during the performance, was taken after we had held the performance a few times. In the beginning it was one of the performing teenagers who were part of our artistic team who performed this text. We realised, however, that at this moment in the performance, the audience participants had actually 'taken over the space'. After careful consideration, we decided to trust in the situation, and ask one of the audience participants to perform this last text. In the event that we would not be able to find someone among the audience, we had a plan for how to proceed. However, it was never a problem to find someone for this task. For ethical reasons, we always made sure that it was done voluntarily, that he or she could practice reading the text with one of us first and that the person was asked in a situation when he or she was not being watched by other audience members. This was possible at that moment in the performance since there were multiple things happening in the space simultaneously. In addition, we made sure to take care of the person after the reading and to give positive feedback. It always turned out to be a positive experience for the person reading. 
After this last reading, the audience participants are given lunch bags and are told they can leave the performance space when they wish. In the performances, there was a feeling of both community and relief in the room - perhaps the latter was because the audience no longer had to participate within a defined framework. Now the room was just an open room where the audience could hang out, but it carried all the stories, encounters and intra-actions of the performance, a space of being and becoming. We often had 'difficulties getting rid of the audience participants' as they just wanted to be there.

Since the performance was mainly performed in schools as part of the Cultural Schoolbag, the audience participants had not decided to be part of the audience themselves. This could result in stronger reactions and it also had ethical implications. As stated above, there is an ethico-onto-epistemology where all the content and intention have an ethics or responsibility, and are interdependent on each other. (Barad, 2007) The ethics operates within, it is immanent in the entanglement of the performance. However, in a performance where the audience participants have not chosen to be there, it is problematic to say that the audience as an agent has equal responsibility, since they have been 'thrown into the situation' and had no chance to prepare their agency. For some audience participants, the experience of the performance was so emotionally intense that it was difficult to participate in the exercises we had initiated.

Coming to terms with the fact that 'each intra-action suggests possibilities for what the world may become' (Barad, 2007) means also paying attention to 'discomforting as well as joyous affective and material relations. Paying attention, and not turning away from "sad" passions.' (Carstens \& Geerts, 2019, p. 920) To take ethical considerations into account in this situation is to also be attentive to the difficult reactions, and to 'stay with the trouble', to put it in Harawayan terms. (2016) In this case, 'staying with the trouble' means acknowledging and accepting the variety of reactions and feelings the performance evokes in the audience participants, also the feelings of discomfort and disharmony. This raises questions related to whether the initiation of participation should only produce social harmony, or whether it could include disharmony, thereby opening for differences. Claire Bishop (2004) uses the term relational antagonism to describe participatory works that expose resistance and opposition, and, in this way, 'provide grounds for rethinking our relationships to the world and to one another' (p. 79). 


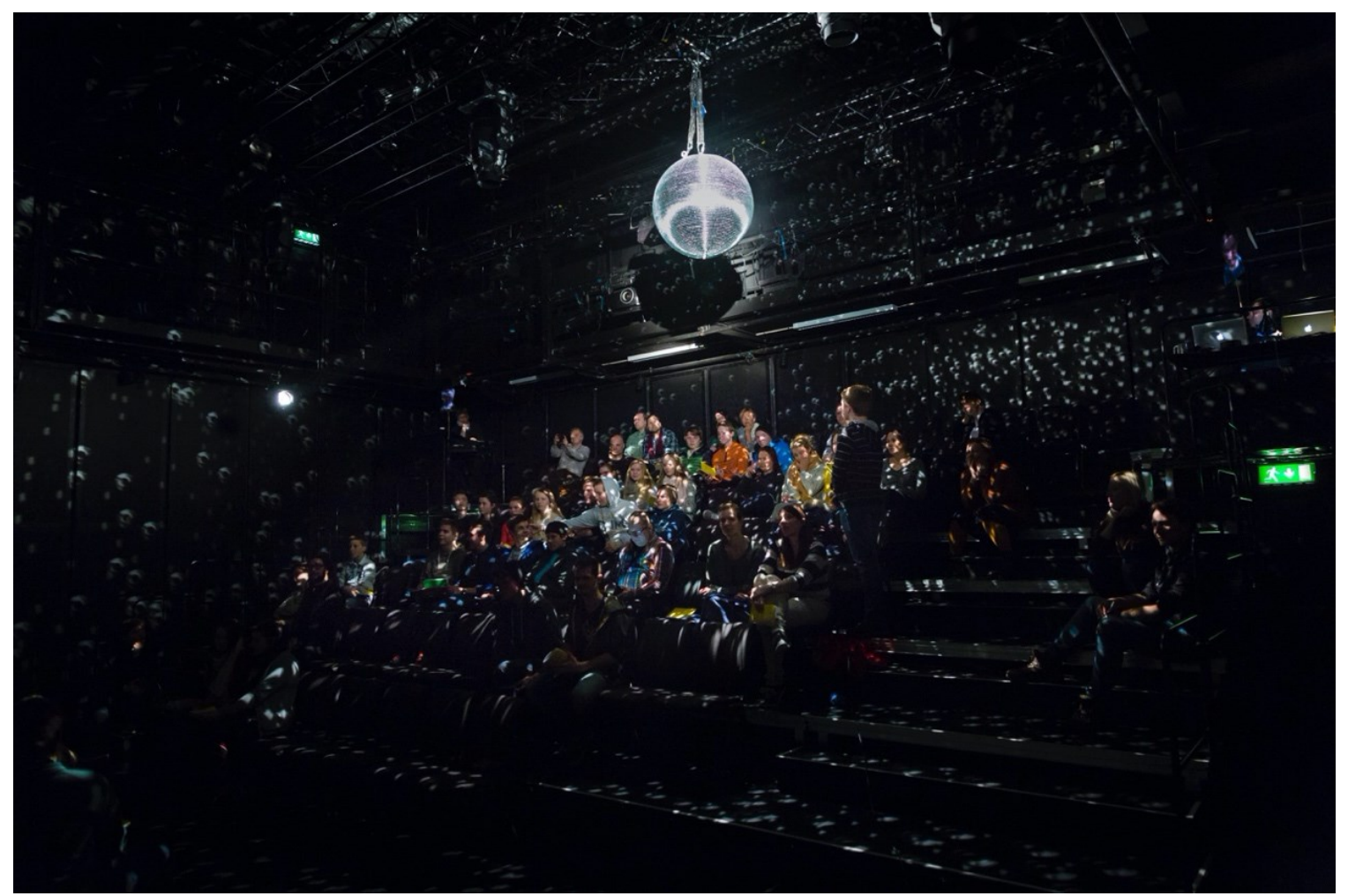

Figure 6. Picture from the end of the performance taken in the direction of the audience. Photo: Marius Fiskum.

\section{Closing remarks on how to initiate a zone of potential}

Rebekka: Most people will be all right.

Kristina: Are you sure?

Rebekka: Yes, I hope so. We just need to practise a bit first. We must exercise quitting or starting or enduring.

These were the last scripted words between me and Rebekka onstage. After this, the audience participants were introduced to several exercises that they could engage with as they wished. They were in intra-action with the situation, practising being in the middle, being influenced by and influencing what was happening. The performance event brought many different people together in a single room, like in school, and showed alternative ways of creating a community, where those who wanted to be included as they were would be included through enactments and their intra-actions with the performance. Looking at the diffractive cuts, the focus is not on who one is when one enters the room, but instead, on what happens in the encounters. In the relations and encounters, responsibility is shared between different agents, and this requires extra attentiveness to unforeseen situations. The 
Kristina Junttila. Exercises in intra-acting: A zone of potential

event can lead to situations that neither the artists nor the audience can foresee, potentially allowing them to create new ways of being together.

I have analysed the performative agents that I have considered to be productive intensities (Massumi, 1995) and as creating a diffractive cut in the production of participation. Each cut is an entanglement and intra-action between different entities, producing new potentials. In the analysis, I separated the different performative agents and analysed their details to consider how they acted differently. These cuts have been analysed specifically because they highlight different issues. In the formulation of the exercises as a performative agent, I highlighted the attention to detail and need for constant readjustment of how we formulate the instructions and intra-actions between the facilitator and audience participant. When looking at the performance object as a performative agent, the emphasis was on how matter is productive and 'triggers' the audience participants in the intra-action. These intraactions can also take the situation in a direction that raises ethical questions around who has responsibility. According to Barad (2012), responsibility is shared between all the agents; it happens in the relations: 'According to agential realism "responsibility" is not about right response, but rather a matter of inviting, welcoming, and enabling the response of the Other. That is, what is at issue is response-ability the ability to respond' (Barad, 2012, p. 81).

With social media as a performative agent, this study discusses how social media are part of our lives today and how it is natural to intra-act with them. Wilde's presence in the performance via Skype intensifies the relationship between her and the audience participants, making the relationship and participation intimate and immediate.

Considering multiplicity as a performative agent, I discussed how the diffractive cuts of multiplicity can enhance inclusion by displaying many ways of participating. With the last performative agent that I analysed, affect, I discussed how it is not possible to anticipate or pre-plan all entanglements. Attentiveness to the situation is a prerequisite for readjusting to each circumstance. In this last diffractive cut, the situation is not necessarily pleasant for the audience participant, which can potentially lead to a rethinking of our relationship to the world and each other.

Following the lines of these diffractive cuts and intra-actions, we can see how the performative agents influence how participation is produced in the entanglement. The consequence of this is that artists and teachers who want to accommodate participation must be aware of how everything - the room, the objects, the performers and the language - is organised. It is necessary to consider the whole complexity of what it is that creates the performance experience, while at the same 
Kristina Junttila. Exercises in intra-acting: A zone of potential

time being aware that the participation and meaning only emerge in the intra-action. This entails imagining what kinds of intra-actions might arise, while at the same time maintaining an attentive and welcoming attitude to what does emerge.

In this performance, the aim was to create new beginnings beyond the norms and expectations associated with the classroom and performance space, where there would be room to include everyone. When breaking norms, there must be consciousness of what the norms are, in this context, the norms of both the theatre and the school. Many individual events break norms, and these small but not insignificant events were what the audience participants intra-acted with. These diffractive cuts of the conventions of the theatre and school destabilised the audience participants in such a way that they could not relax in a safe format. Audience participants must be in constant intra-action with the disturbances of the space. This not only initiates participation, but also opens a space for the unpredictable to happen. By looking at how participation is produced in the intra-action, in the relations, in the in-between, we can also see how we can accommodate a zone of potential.

This zone of potential is produced by the aesthetic and ethical choices made in the performance, and how they intra-act. The zone of potential frames different ways of being in the space, which can potentially open up a new way of looking at or being in the future. However, it is also important to note that the performance was a temporary space and that this temporariness has limitations as a catalyser for lasting transformations. However, the performance is a relevant place to practise and experiment with new ways of being together and encountering multiple realities and accepting differences.

\section{A last image}

We see a teacher drawing a heart on a chair using a permanent marker, while a girl is doing the exercise about not quitting and is already taped to the green chair. One brave pupil is doing an exercise about quitting, calling his parents to tell them that he will quit school. After a while, he will tell them that making the phone call is just an exercise. Some people are touching the sound triggers in a small group; another group is reading texts aloud using the microphone. One boy is alone, hiding in his hoodie. Most of the audience participants are just sitting or standing around.

To be a teenager is shit. So much shit just comes towards you. So fast. Everything at once. Never one by one, but everything at once. And then there is this fucking puberty and I fall in love all the fucking time. All I can 
Kristina Junttila. Exercises in intra-acting: A zone of potential

say about that is: Why do you do this to me? (Text from the performance, written by a teenager)

The performative agents in this study have initiated different forms of participation and had an effect we could not necessarily have anticipated or always wished for. This situation stops here, but it also continues in many directions. It has temporarily opened a new way of being together and given space for the complexities and diversity that are part of teenagers' lives. I look ahead and ask: What is the potential of this situation?

\section{About the author}

Kristina Junttila is a performance artist, director and pedagogue working in the field of live art. She is doing a PhD at the Arts Academy in Troms $\varnothing$ and have recently started as Associate Professor in Performing Arts at the Music Conservatory in Troms $\varnothing$, both placed at UMAK, UoT, The Arctic University of Norway. She holds a Masters Degree in Live Art and Performance Studies, as well as in Theatre Pedagogy from The Theatre Academy, University of the Arts, Helsinki. Junttila have worked nationally and internationally as an artist for twenty years, and is today in the artistic board of Ferske Scener and artistic leader of Snakk for deg sjøl in Tromsø.

\section{Referanser}

Agamben, G., \& Heller-Roazen, D. (1999). Potentialities : collected essays in philosophy. Stanford, Calif: Stanford University Press.

Bala, S. (2018). The gestures of participatory art: Manchester University Press. https://doi.org/10.7228/manchester/9781526100771.001.0001

Balme, C. B. (2019). Audio Theatre - The mediatisation and politicization of theatrical space.

Barad, K. (2003). Posthumanist Performativity: Toward an Understanding of How Matter Comes to Matter. Signs: Journal of Women in Culture and Society, vol. 28(no. 3), 30. https://doi.org/10.1086/345321

Barad, K. (2007). Meeting the Universe Halfway : Quantum Physics and the Entanglement of Matter and Meaning. North Carolina: Duke University Press. https://doi.org/10.1515/9780822388128

Barad, K. (2012) Intra-actions/Interviewer: A. Kleinmann. (Vol 13), Mousse Magazine, Special dOCUMENTA.

Berg, I. T. (2017). Participation to the people! Locating the popular in Rimini Protokoll's Home Visit Europe. Nordic theatre studies [electronic resource], 29, 162-183. https://doi.org/10.7146/nts.v29i2.104610 
Kristina Junttila. Exercises in intra-acting: A zone of potential

Bishop, C. (2004). Antagonism and Relational Aesthetics. October, 51-79. https://doi.org/10.1162/0162287042379810

Bishop, C. (2012). Artificial hells : participatory art and the politics of spectatorship. London: Verso.

Boyd, M. (2015). Towards a performative multi species aesthetics. Antennae: The Journal of Nature in Visual Culture (31), 9 - 29.

Carstens, D., \& Geerts, E. (2019). Ethico-onto-epistemology. Philosophy Today, 63(4). https://doi.org/10.5840/philtoday202019301

Deleuze, G. (1992). What is an Event? (T. Conley, Trans.). Minnesota: University of Minnesota Press.

Goldberg, R. (2000). Here and Now. In T. Warr (Ed.), The Artist's body. London: Phaidon Press.

Haraway, D. (1997). Modest_Witness

@Second_Millennium.FemaleMan@_Meets_OncoMouseTM: Feminism and Technoscience. New York: Routledge.

Haraway, D. J. (1991). A cyborg Manifesto. Science, technology and socialistfeminism in the late twentieth century. In - mangler det noe her, og skulle dette stått før D, Haraway (1997) siden det er utgitt før?.

Haraway, D. J. (2016). Staying with the trouble : making kin in the Chthulucene. https://doi.org/10.1515/9780822373780

Hickey-Moody, A., \& Page, T. (2016). Arts, Pedagogy and Cultural Resistance. New Materialisms. London: Rowman \& Littlefield International.

Jackson, S. (2011). Social works : performing art, supporting publics. Abingdon: Routledge. https://doi.org/10.4324/9780203852897

Kester, G. H. (2004). Conversation pieces : community and communication in modern art. Berkeley, Calif: University of California Press.

Koro-Ljungberg, M., Löytönen, T., \& Tesar, M. (Eds.). (2017). Disrupting Data in Qualitative Inquiry. Entanglements with the Post-Critical and PostAnthropocentric. New York: Peter Lang Publishing. https://doi.org/10.3726/b11070

Lenz Taguchi, H. (2011). Investigating, Learning, Participation and Becoming in Early Childhood Practices with a Relational Materialist Approach. Global studies of Childhood, Volume 1 (Number 1). https://doi.org/10.2304/gsch.2011.1.1.36

Lenz Taguchi, H. (2012). Pedagogisk dokumentation som aktiv agent : introduktion til intra-aktiv pedagogik. Malmö: Gleerups.

Manning, E. (2014). Thought in the act : passages in the ecology of experience. Minneapolis, Minnesota: University of Minnesota Press. https://doi.org/10.5749/minnesota/9780816679669.001.0001 
Kristina Junttila. Exercises in intra-acting: A zone of potential

Marabelli, M., \& Page, X. (2018). Performing Identity through Social Media: A

Sociomaterial Perspective. https://doi.org/10.2139/ssrn.3134979

Massumi, B. (2015). Politics of Affect: Polity Press.

Nagel, L., \& Hovik, L. (2014). Interaktiv scenekunst for barn - tyranni eller magi?

Østern, A.-L., \& Moxness, L. (2017). Å undervise i sirkus som kunstfag - en studie av sammenflettede tilblivelser i intra-aktiv sirkusdidaktikk. På Spissen, 3, 39 - 40.

Østern, T. P., \& Hovik, L. (2017). Med-koreografi og med-dramaturgi som diffraksjon. Med som metodologisk agent for skapende og forskende prosesser i Baby Body. Journal for Research in Arts and Sports Education, Vol. 1, 43 - 58. https://doi.org/10.23865/jased.v1.906

Phelan, P. (2004). On Seeing the Invisible: Marina Abramovic's The House with the Ocean View. In A. Heathfield (Ed.), Live Art and Performance. London: Tate Publishing.

Rancière, J. (2009). The emancipated spectator. London: Verso Books.

Sandvik, N. (2015). Posthumanistiske perspektiver. Bidrag til barnehageforskningen. In A. M. Otterstad \& A. B. Reinertsen (Eds.), Metodefestival og øyeblikksrealisme - eksperimenterende kvalitative forskningspassasjer: Fagbokforlaget.

Sayal-Bennett, A. (2018). Diffractive Analysis: Embodied Encounters in Contemporary Artistic Video Practice. Tate Papers, no. 29. Retrieved from https://www.tate.org.uk/research/publications/tate-papers/29/diffractiveanalysis

Schechner, R. (2006). Performance studies: an introduction (2nd ed.). New York: Routledge.

Scott, J. (2015). Matter Mattering: "Intra-activity" in live media performance. Body, Space and Technology, 14. https://doi.org/10.16995/bst.33

Shouse, E. (2005). Feeling, Emotion, Affect. M/C Journal. A journal of Media and Culture, 8(6). Retrieved from https://doi.org/10.5204/mcj.2443

Stien, K., Kramvig, B., \& Liabø, R. B. (2015). To be or not to be: når å skrive er å skrive seg inn i et fellesskap. In A. M. Otterstad \& A. B. Reinertsen (Eds.), Metodefestival og øyeblikksrealisme : eksperimenterende kvalitative forskningspassasjer. Bergen: Fagbokforl.

Tillman, R. (2015). Toward a new materialism: Matter as dynamic. Minding Nature, 8(1), 6. 
Kristina Junttila. Exercises in intra-acting: A zone of potential

\section{Own sources cited in the text:}

Journal written by the author after public performances at Hålogaland Theatre and on tour with the Cultural Schoolbag, 13.10-21.10.2016.

Audio-recording of a reflective dialogue/interview between the author, Rakel Nystabakk (sound designer) and Rebekka Brox Liabø (project manager), 20.10.2016.

\section{Performances}

Hålogaland Theater, Troms $\varnothing 17^{\text {th }}-21^{\text {st }}$ of March 2015. Audience: 3 performances for adult "art audiences" (many teachers) and 3 performances for schools, age group. $13-16$ years old.

Arctic Arts Festival, Harstad: $20^{\text {th }}$ of June 2016. Audience: Adult "art audience".

The Cultural Schoolbag in Troms and Finnmark: October 2016, January and February 2017. Audience: teenagers aged 13 - 16 years old, during school hours.

\section{Artistic team}

Rebekka Brox Liabø - project manager, script writer and performer,

Kristina Junttila (author) - artistic director, audience participation designer and performer

Rakel Nystabakk - sound designer and performer,

Linda Nilsen - visual designer and performer 